\title{
Implementasi Konsep Tanggung Jawab Sosial sebagai Upaya Meningkatkan Efektivitas Pengelolaan BUMDes
}

\author{
Hafid Aditya Pradesa ${ }^{1}$, Iin Agustina ${ }^{2}$ \\ ${ }^{1}$ Politeknik STIA LAN, Bandung, Indonesia \\ ${ }^{2}$ Magister Manajemen Universitas Brawijaya, Malang, Indonesia \\ *email: hafidap85@gmail.com
}

\begin{abstract}
This study aims to initiate a model for the social responsibility framework of BUMDes. This research has the aim of initiating a model for the social responsibility framework of BUMDes, by considering its institutional structure as a strategic business entity and becoming one of the main pillars for developing the economic potential in rural areas. Considering stakeholders from BUMDes and the social responsibility domain framework based on the Triple Bottom Line concept, the potential impact of BUMDes existence is well recognized and the social responsibility domain for BUMDes is offered in this article. The practice of social responsibility for BUMDes has not become an interesting area or even has an urgency to be studied. Eventhough, BUMDes is the dominant engine of economic growth - creators of value principles and managerial resources - and that BUMDes have an obligation to contribute to the economic growth of rural communities - encourages the need to promote sustainability among stakeholders and increase the sustainability of business that managed by BUMDes.
\end{abstract}

Keywords: Social Responsibility, Triple Bottom Line, Village Owned Enterprises (BUMDes)

\section{PENDAHULUAN}

Undang-Undang tentang desa telah memberi mandat pada masyarakat (pemerintah atau semua stakeholders pembangunan) untuk memaksimalkan implementasi tentang desa membangun. Program yang telah dijalankan sebelumnya lebih bersifat top down, namun saat ini secara substansial pembangunan desa cenderung diserahkan pada desa tersebut. Peran pemerintah pusat maupun daerah lebih kepada fasilitator, pemberi bantuan dana, serta pembinaan dan pengawasan, sehingga diperlukan perhatian khusus terhadap desa. Hal ini yang mendorong lahirnya konsep Alokasi Dana Desa yang dikuatkan dengan
Peraturan Pemerintah Nomor 72 Tahun 2005 (Azwardi \& Sukanto, 2014).

Berdasarkan UU No. 6 Tahun 2014 Tentang Desa Pasal 1 Ayat (6) yang membahas Badan Usaha Milik Desa (BUMDesa) dijelaskan bahwa :"BUMDesa adalah badan usaha yang seluruh atau sebagian besar modalnya dimiliki oleh desa melalui penyertaan secara langsung yang berasal dari kekayaan desa yang dipisahkan guna mengelola aset, jasa pelayanan, dan usaha lainnya untuk sebesar-besarnya kesejahteraan masyarakat desa."

Berdasarkan UU tersebut maka posisi dan potensi BUMDes sangat penting dan strategis mempertimbangkan posisinya sebagai: 1) Lembaga ekonomi masyarakat 
yang berperan mendorong perekonomian di desa, 2) Usaha desa milik kolektif dengan keunikan yang dimiliki serta digerakkan oleh aksi kolektif antara pemerintah desa dan masyarakat (Public and Community Partnership), 3) Bentuk usaha desa yang dibentuk atas dasar komitmen bersama masyarakat desa untuk saling bekerja sama dan menggalang kekuatan ekonomi rakyat demi mewujudkan kesejahteraan dan kemakmuran masyarakat desa.

Pengembangan dan pembentukan BUMDesa merupakan prospek menjanjikan untuk menguatkan dan memberdayakan lembaga atau pelaku ekonomi desa. Beberapa potensi ekonomi yang dimiliki di desa melalui BUMDes terdiri dari beberapa jenis bisnis, diantaranya: 1) Bisnis sosial (social business) sederhana yang memberikan pelayanan umum (serving) kepada masyarakat dengan harapan dapat memperoleh keuntungan finansial, 2) Bisnis penyewaan (renting) barang yang memberikan pelayanan penyewaan barang kebutuhan masyarakat desa dengan harapan untuk memperoleh Pendapatan Asli Desa, 3) Usaha perantara (brokering) yang memberikan jasa pelayanan kepada warga, 4) Bisnis yang berproduksi dan/atau berdagang (trading) yang menyediakan barang-barang tertentu untuk memenuhi kebutuhan masyarakat maupun dipasarkan pada skala pasar yang lebih luas, 5) Bisnis keuangan (financial business) yang memenuhi kebutuhan usaha-usaha skala mikro yang dijalankan oleh pelaku usaha ekonomi desa, dan 6) Usaha bersama (holding) sebagai induk dari unit-unit usaha yang dikembangkan masyarakat desa baik dalam skala lokal desa maupun kawasan perdesaan.

Dewasa ini, keberadaan sebuah BUMDes tidak bisa dipisahkan dari masyarakat desa yang merupakan bagian integral dari lingkungan eksternalnya. Ditinjau dalam aspek ekonomi, BUMDes dapat memperoleh keuntungan, karena mempertimbangkan bentuk organisasi ini adalah sebuah "badan usaha". Dalam hal ini tentu motif tujuan ekonomi yakni menciptakan profit bagi sebuah BUMDes sangat wajar mengingat tujuan awal pembentukan BUMDes bukan semata hanya untuk legitimasi dari penggunaan dana desa yang digalakkan pemerintah, tetapi juga sebagai bentuk riil dalam mendorong dan mengembangkan potensi perekonomian desa. Sementara dari aspek sosial BUMDes harus memberikan kontribusi secara langsung kepada masyarakat yaitu meningkatkan kualitas kehidupan masyarakat dan lingkungannya.

Melihat fenomena tersebut, maka BUMDes dapat diibaratkan layaknya dua sisi koin, pada satu sisi sebagai organisasi yang membawa misi sosial dan di sisi lain membawa misi ekonomi karena harus membawa manfaat bagi desa (peningkatan pendapatan desa). Pernyataan ini sesungguhnya memberikan implikasi yang menyulitkan bagi BUMDes. Ditinjau dari perencanaan strategis, positioning sebuah organisasi harus jelas sebagai dasar dalam melakukan aktivitasnya. Ketika BUMDes dipersepsikan sebagai organisasi yang membawa dua misi (ekonomi dan sosial) maka pengelolaan stakeholder menjadi penting karena hal ini akan sama dengan mengelola kepentingan agar tidak terjadi konflik maupun tindakan, sikap, maupun perilaku yang tidak etis.

Mengelola stakeholder bermuara pada konsep praktik etika dalam mengelola bisnis atau usaha, dengan hal yang paling dikenali adalah konsep tanggung jawab sosial perusahaan (corporate social responsibility atau CSR). Konsep teoritis maupun hasil empiris terdahulu tentang praktek CSR, mayoritas atau sebagian besar mengulas locus atau unit analisisnya pada perusahaan atau organisasi bisnis (Hou \& Reber, 2011; Jamali \& Mirshak, 2007; Sen \& Bhattacharya, 2001; Sen, Bhattacharya, \& Korschun, 2006). Sebagaimana telah diutarakan oleh Kristia (2019) bahwa model bisnis Triple Bottom Line dan upaya berkelanjutan dalam mengelola bisnis telah diterapkan pada pasar komunitas telah menunjukkan bahwa gagasan pengelolaan berkelanjutan dapat diaplikasikan dalam tipe organisasi yang 
beragam. Pengelolaan berkelanjutan diyakini dapat diterapkan pada organisasi BUMDes.

Berdasarkan hal tersebut maka penelitian ini mempunyai tujuan untuk menggagas tentang model kerangka tanggung jawab sosial dari BUMDes, dengan mempertimbangkan struktur kelembagaannya sebagai badan usaha yang strategis dan menjadi salah satu tumpuan utama untuk pengembangan potensi perekonomian di wilayah desa.

Penelitian ini dikategorikan sebagai conceptual paper yang bermuara pada upaya menciptakan pengetahuan baru dengan membangun sumber informasi yang dipilih secara cermat yang digabungkan sesuai dengan seperangkat norma. Artikel konseptual mengacu pada berbagai konsep, aliran literatur, dan teori yang memainkan peran berbeda sehingga selanjutnya akan dibahas konsep dan teori yang terkait dengan implementasi tanggung jawab sosial pada BUMDes. Dalam kasus makalah konseptual tentang implementasi tanggung jawab sosial pada BUMDes, argumen tidak diturunkan dari data empiris maupun data dalam pengertian tradisional tetapi melibatkan asimilasi dan kombinasi bukti dalam bentuk konsep dan teori yang dikembangkan sebelumnya dalam tulisan atau artikel terdahulu.

\section{Teori dan Pemetaan Stakeholder dari BUMDes}

Konsep atau teori stakeholder yang berlaku saat ini adalah bentuk "paradigma dominan dari CSR" (Frederick, 1998). Hubungan pemangku kepentingan dengan organisasi bisnis merupakan lokus dari praktik yang kemudian diposisikan sebagai mekanisme operasional untuk memediasi tindakan organisasi dan sifat-sifat yang muncul dari sistem sosio-kultural yang lebih besar (Freeman, 1994; Freeman, Wicks, \& Parmar, 2004). Dengan kata lain, pada tingkat hubungan stakeholder yang lebih banyak walaupun tidak harus meliputi seluruh kelompok stakeholder, kekuatan struktural dan budaya yang bersifat mendukung atau melawan modalitas dari CSR menjadi lebih mudah dikenali dan bersifat lebih nyata bagi perusahaan (Phillips, Freeman, \& Wicks, 2003). Oleh karena itu tekanan bagi organisasi akan selalu muncul dari pemangku kepentingan, terutama tentang bagaimana organisasi merespons melalui tindakan sosial yang dilakukannya. Identifikasi stakeholder berdasarkan posisinya, akan mengarahkan kepada perlunya BUMDes untuk dapat bertanggungjawab kepada beberapa kelompok stakeholder yang terkait, antara lain sebagai berikut :

Tabel 1. Identifikasi Stakholder BUMDes

\begin{tabular}{|c|c|c|c|}
\hline \multicolumn{2}{|c|}{ Stakeholder Internal } & \multicolumn{2}{|c|}{ Stakeholder Eksternal } \\
\hline Pihak & $\begin{array}{c}\text { Kewajiban } \\
\text { (Kepentingan) }\end{array}$ & Pihak & $\begin{array}{c}\text { Kewajiban } \\
\text { (Kepentingan) }\end{array}$ \\
\hline $\begin{array}{c}\text { Pemerintah } \\
\text { Desa }\end{array}$ & $\begin{array}{l}\text { Profit yang } \\
\text { tinggi (dan atau } \\
\text { benefit yang } \\
\text { maksimal) }\end{array}$ & Pelanggan & $\begin{array}{c}\text { Produk atau } \\
\text { jasa yang } \\
\text { berkualitas }\end{array}$ \\
\hline $\begin{array}{l}\text { Manajer } \\
\text { BUMDes }\end{array}$ & $\begin{array}{l}\text { Kompensasi/ } \\
\text { Imbalan (Gaji, } \\
\text { insentif) yang } \\
\text { adil }\end{array}$ & Mitra Kerja & $\begin{array}{l}\text { Perlakuan adil } \\
\text { dan etis }\end{array}$ \\
\hline $\begin{array}{l}\text { Karyawan } \\
\text { BUMDes }\end{array}$ & $\begin{array}{c}\text { Kompensasi/ } \\
\text { Imbalan (Gaji, } \\
\text { insentif) yang } \\
\text { adil }\end{array}$ & $\begin{array}{c}\text { Pemerintah } \\
\text { Daerah }\end{array}$ & $\begin{array}{c}\text { Pemenuhan } \\
\text { kewajiban atas } \\
\text { regulasi, } \\
\text { Pembayaran } \\
\text { (serta insentif) } \\
\text { Pajak } \\
\text { Dampak sosial, } \\
\text { ekonomi, dan } \\
\text { lingkungan, } \\
\text { maupun } \\
\text { hubungan } \\
\text { ketenagakerjaan } \\
\text { yang stabil bagi } \\
\text { anggota } \\
\text { masyarakat }\end{array}$ \\
\hline
\end{tabular}

Sumber : Dikembangkan dalam artikel ini.

Literatur tentang manajemen atau analisa stakeholder sering memunculkan pertimbangan kemungkinan tuntutan pemangku kepentingan sebagai kekuatan kausal yang menentukan isi dan modalitas dari praktek dari tanggung jawab sosial. Freeman et al., (2004) memperluas konsep stakeholders, dengan basis pada penguatan legitimasi dari organisasi (untuk tindakan yang dilakukannya) dalam mengelola kepentingan yang dimiliki oleh stakeholder. Proksimal bagi organisasi bisnis adalah hubungan diantara perusahaan dengan pemangku kepentingannya (firm-stakeholder relationship). Perkembangan ini yang menyebabkan tanggung jawab sosial semakin dikaitkan dengan isu-isu etika, hubungan 
ketenagakerjaan, pemberdayaan ekonomi, corporate social responsiveness, corporate citizenship dan corporate governance. CSR tidak hanya mempunyai isu-isu charity, namun juga termasuk isu business sustainability. Lapisan struktur sosial adalah domain sebenarnya dengan kemungkinan paling besar dalam mekanisme praktek tanggung jawab sosial. Legitimasi dari sebauh perusahaan dapat tercermin dalam konsep triple bottom line (profit, people dan planet). Kondisi ini menyebabkan perluasan debat justifikasi praktek CSR (misal : Harrison \& Freeman, 1999; Hou \& Reber, 2011; Husted \& Allen, 2007). Oleh karena itu sangat penting untuk melakukan pemetaan stakeholder dari BUMDes untuk mengetahui siapa saja pihak yang berkepentingan dengan adanya BUMDes di suatu desa, sehingga menjadi basis awal dalam penerapan tanggung jawab sosialnya.

Prinsip-prinsip dari tanggung jawab sosial telah lama menjadi bagian dari praktik bisnis yang mencerahkan dan lebih etis, tetapi konsep ini telah mengalami peningkatan dan perkembangan yang mengejutkan dalam beberapa tahun terakhir. Namun demikian, konsep tersebut belum dianut secara seragam, dengan pandangan yang berbeda-beda tentang potensi manfaat dan penerapannya. Sebagai ilustrasi Gambar 1 yang mengulas tiga domain tanggung jawab sosial, yakni bagaimana memenuhi aspek ekonomi (menciptakan profit), aspek legal (mematuhi aturan), dan aspek etis (mengurangi dampak negatif). Model yang diusulkan, "TigaDomain Model CSR," diekstrapolasi dari karya dasar Carroll, diusulkan sebagai cara alternatif untuk menggambarkan kegiatan dan orientasi CSR yang meliputi komunitas bisnis.

Model tiga domain juga membantu menghilangkan asumsi inheren dari hubungan hierarkis di antara domain yang beberapa dirasakan dalam penggambaran piramida tanggung jawab sosial oleh Carroll. Hal ini memberikan perluasan deskripsi untuk domain konstruk yang lebih lengkap untuk mengklasifikasikan kegiatan perusahaan. Salah satu kesulitan yang dihadapi adalah kemampuan untuk mengklasifikasikan organisasi bisnis dan aktivitasnya dengan benar dalam konstruk tanggung jawab sosial (Clarkson, 1995). Model baru ini dimaksudkan untuk memberikan cara yang lebih tepat dan kerangka kerja teoritis yang digunakan untuk mengategorikan Kegiatan tanggung jawab sosial.

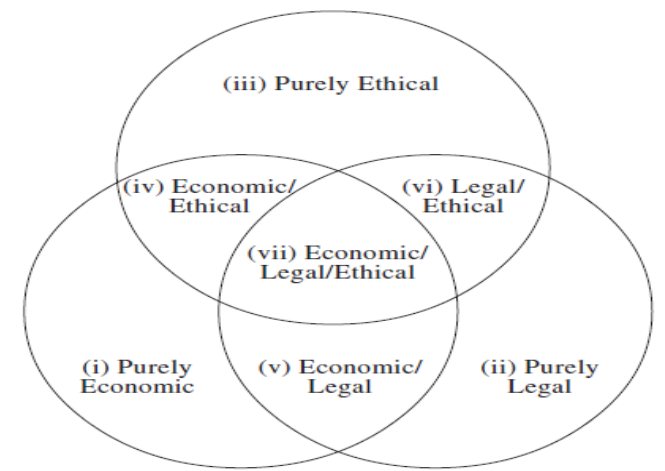

Gambar 1. Model 3 Domain Dari Tanggung Jawab Sosial Berdasarkan Konsep Triple Bottom Line

Diharapkan pimpinan atau manajer
yang mengelola BUMDes dapat merefleksikan tindakan yang dilakukan BUMDes dan di mana tindakan tersebut harus diklasifikasikan dalam model tiga domain, hal ini memungkinkan peningkatan pemahaman tentang hubungan antara bisnis yang dikelola BUMDES dan masyarakat dan lebih khusus lagi hubungan diantara aspek ekonomi, hukum, dan etika.

Definisi tanggung jawab sosial perusahaan atau corporate social responsibility (CSR) secara umum menunjukkan bahwa adalah tidak ada sesuatu yang baru pada tingkatan konseptual; dimana sebuah entitas bisnis selalu mempunyai dampak sosial, ekonomi dan lingkungan, yang terkait dengan stakeholder (Bhattacharya, Sahay, Arora, \& Chaturvedi, 2004; Luo \& Bhattacharya, 2006; Sen et al., 2006). Perusahaan atau organisasi bisnis akan selalu berhadapan dengan pemerintah, pelanggan atau pemilik, yang dihadapkan dengan peraturan terkait. Hal ini telah diatur sampai pola mapan dikembangkan dari tahun ke tahun. Bagaimanapun, terdapat perbedaan yang muncul terutama pada suatu tingkat operasional. Dalam kaitan dengan globalisasi, 
konteks di mana bisnis beroperasi sedang berubah kepada suatu langkah yang terus meningkat cepat. Stakeholder baru mulai bermunculan dan peraturan atau perundangundangan nasional yang berbeda telah meletakkan harapan baru atas suatu kepentingan dan mengubah bagaimana dampak sosial, ekonomi dan lingkungan harus secara optimal seimbang terutama di dalam pengambilan keputusan (Sen \& Bhattacharya, 2001; Sen et al., 2006) termasuk dalam mengalokasikan sumber daya yang dimiliki organisasi. Sehingga, dalam konteks yang demikian maka pengelolaan tanggung jawab sosial diperlukan dalam organisasi, sebagai tambahan atas pola yang telah terbentuk sebelumnya, untuk kemudian dikembangkan dan diterapkan menjadi strategi bisnis yang lebih mapan. Tanggung jawab sosial merupakan mekanisme bagi organisasi untuk secara sukarela mengintegrasikan kesadaran dan perhatiannya terhadap aspek lingkungan serta aspek sosial ke dalam kegiatan operasionalnya dan interaksinya dengan stakeholders (Dahlsrud, 2008; Eberle, G.Berens, \& Li, 2013).

\section{Praktek Tanggung Jawab Sosial di Desa}

Prinsip tanggung jawab sosial telah mengakar pada praktik bisnis yang mencerahkan bagi para pemangku kepentingan. Tanggung jawab sosial yang diupayakan oleh entitas usaha dapat diwujudkan dalam berbagai aspek antara lain meliputi pendidikan, ekonomi, kesehatan, sosial dan lingkungan (Nurbaiti \& Bambang, 2017). Kecenderungan penyelenggaraan tanggung jawab sosial dari entitas usaha adalah mengatasi dampak sosial dan ekonomi dan menyelaraskan program dengan prioritas pembangunan daerah. Selama ini desa hanya menjadi lokus, tempat, atau obyek dari pelaksanaan tanggung jawab sosial perusahaan yang membutuhkan legitimasi atas tindakan perusahaan untuk dinilai etis (Kolopaking, Septianto, \& Ambarita, 2019; Nurbaiti \& Bambang, 2017). Di sisi lain terdapat ketergantungan desa yang meningkat atas pemberian bantuan CSR dari perusahaan.
Dengan adanya BUMDes maka diharapkan terjadi pergeseran bahwa desa juga berperan penting dalam pelaksanaan tanggung jawab sosial dengan lebih otonom.

Setidaknya terdapat tiga alasan penting mengapa BUMDes harus melaksanakan tanggung jawab sosialnya di desa. Pertama, BUMDes merupakan bagian integral dari masyarakat desa dan oleh karenanya wajar bila BUMDes memperhatikan kepentingan masyarakat desa sebagai salah satu stakeholder utamanya. BUMDes harus menyadari bahwa organisasi beroperasi dalam satu tatanan lingkungan masyarakat desa. Kegiatan tanggung jawab sosial berfungsi sebagai kompensasi atau upaya imbal balik atas penguasaan sumber daya (alam atau ekonomi) oleh BUMDes yang mungkin bersifat eksploratif dan ekspansif, disamping sebagai kompensasi sosial karena timbul konsekuensi dalam masyarakat desa. Kedua, BUMDes dan masyarakat desa idealnya memiliki hubungan yang bersifat simbiosis mutualisme.

Tabel 2. Dampak Potensial dari BUMDes

\begin{tabular}{ll}
\hline \multicolumn{1}{c}{ Dampak Positif } & \multicolumn{1}{c}{ Dampak Negatif } \\
Menyediakan pekerjaan, & Mengancam struktur sosial \\
gaji, dan manfaat & dalam masyarakat \\
Menyediakan produk dan & Keterikatan dalam perilaku \\
layanan & non-kompetitif \\
Menyediakan sumber & Membebankan biaya \\
pendapatan bagi Desa & kepada pihak lain \\
Mendorong penciptaan & Mengeksploitasi sumber \\
kemakmuran bagi pribadi & daya atau potensi yang \\
dan publik & dimiliki oleh desa dengan \\
& pengembalian yang masih \\
& belum seimbang \\
& Menciptakan hubungan \\
& saling ketergantungan \\
\hline
\end{tabular}

Sumber : Dikembangkan dalam artikel ini.

Dalam upaya mendapatkan dukungan dari masyarakat desa, wajar bila BUMDes dituntut memberikan kontribusi positif kepada masyarakat di sekitarnya, sehingga bisa tercipta harmonisasi hubungan bahkan pendongkrakan citra dan performa BUMDES. Ketiga, kegiatan tanggung jawab sosial BUMDes merupakan salah satu cara untuk meredam atau bahkan menghindarkan konflik sosial yang terjadi. 
Meskipun ada banyak contoh di mana perusahaan yang murni profit oriented telah mengambil keuntungan sebesar-besarnya dari wilayah yang sedang berkembang dan populasi yang dikecualikan secara sosial, dampak potensial dari kontribusi usaha dan atau bisnis terhadap pembangunan tidak dapat diabaikan dan kemungkinan akan sangat penting untuk mengurangi kemiskinan dalam jangka panjang. Dalam hal ini kelompok yang dikecualikan secara sosial adalah populasi yang telah dikeluarkan dari keuntungan pertumbuhan ekonomi dan kemajuan sosial melalui pengucilan dari masyarakat berdasarkan budaya, identitas sosial, karakteristik bersama, dan lainnya. Bisnis dapat memiliki dampak positif pada kesehatan dan pembangunan melalui tiga jalan utama yaitu: 1) penyediaan lapangan pekerjaan, 2) pengembangan masyarakat dan kegiatan filantropi, dan 3) tanggung jawab sosial strategis dari bisnis inti. Dua hal pertama dapat dikelompokkan secara luas sebagai praktek tanggung jawab sosial secara tradisional. Konsep tanggung jawab sosial tradisional dan strategis dibedakan dalam motivasi, implementasi, dan dari dampaknya masing-masing.

Terdapat dua kategori dampak potensial (positif dan negatif) dari keberadaan BUMDes, sebagaimana tercantum pada Tabel 2. Dampak potensial tersebut tentu harus dipertimbangkan dan diantisipasi dalam pengelolaan BUMDes. Diluar dampak yang diidentifikasi, permasalahan mendasar bagi sebuah Bumdes terutama kondisi eksternal seperti iklim berusaha yang belum kondusif, keterbatasan informasi dan akses pasar, rendahnya produktivitas, keterbatasan permodalan, maupun jiwa dan semangat kewirausahaan masyarakat. Permasalahan tersebut akan menjadi tantangan bagi BUMDes untuk tetap berprinsip teguh dalam penerapan tanggung jawab sosialnya. Sebagai contoh beberapa inisiatif tanggung jawab sosial bermuara pada target pengembangan masyarakat.
Namun beberapa hal yang sebelumnya diyakini merupakan bentuk tanggung jawab sosial dari BUMDes ketika ditelaah menjadi kurang tepat apabila hanya fokus kepada aspek sosial. Oleh karena itu BUMDes dapat dipandang sebagai institusi yang terlegitimasi dan berpotensi besar dalam memaksimalkan praktek tanggung jawab sosial di masyarakat desa.

\section{METODE}

Penelitian ini dikategorikan sebagai conceptual paper yang bermuara pada upaya menciptakan pengetahuan baru dengan membangun sumber informasi yang dipilih secara cermat yang digabungkan sesuai dengan seperangkat norma. Artikel konseptual mengacu pada berbagai konsep, aliran literatur, dan teori yang memainkan peran berbeda

\section{HASIL DAN PEMBAHASAN}

Upaya penting untuk menjembatani kesenjangan antara ekonomi dan harapan lainnya ditawarkan oleh Archie Carroll (1979). Usahanya memuncak dalam berikut definisi yang diusulkan mengenai tanggung jawab sosial perusahaan: Tanggung jawab sosial bisnis meliputi ekonomi, hukum, etika, dan harapan diskresi yang dimiliki masyarakat terhadap organisasi diberikan waktu.

Konsep yang disampaikan oleh Carroll (1991) tersebut menunjukkan pentingnya konsep tanggung jawab sosial dalam sebuah perusahaan. Dalam memaknai piramida tanggung jawab sosial tersebut, maka sebuah "usaha" yang dijalankan dalam skala atau bentuk apapun disarankan untuk menjadi profitabel terlebih dahulu. Hal ini semestinya juga berlaku pada BUMDes, merujuk pada pendirian Bumdes adalah untuk menggerakkan dan menata potensi ekonomi desa melalui Bumdes. 


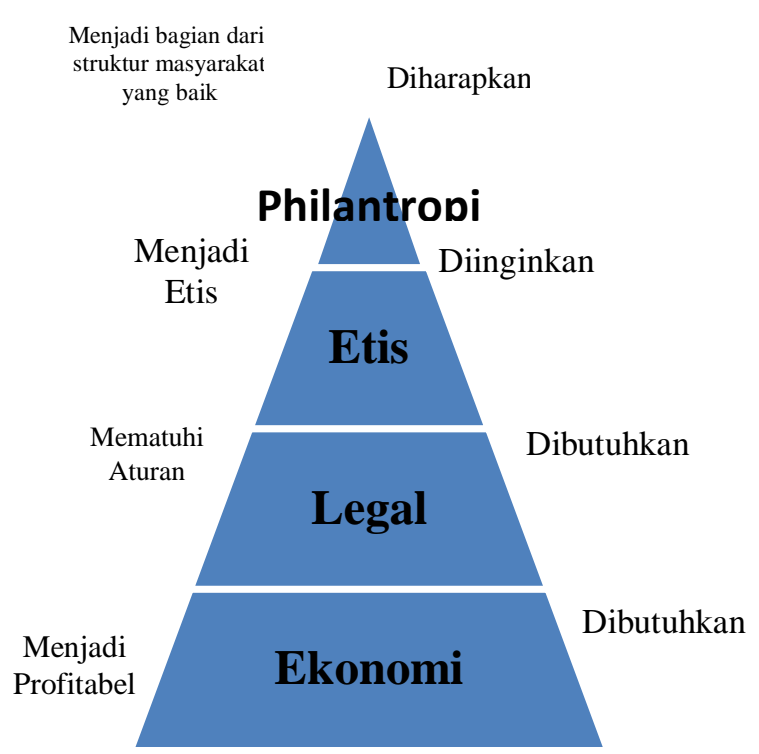

Gambar 2. Piramida Tanggung Jawab Sosial

Terlepas dari kecenderungan yang dirasakan oleh para pemangku kepentingan, konsep penerapan tanggung jawab sosial belum secara meyakinkan dapat menetapkan biaya dan manfaat dari partisipasi organisasi dalam kegiatan yang bertanggung jawab secara sosial, tidak terkecuali adalah organisasi BUMDes. Meskipun dukungan yang luas saat ini untuk aktivitas bisnis dan sosial dari BUMDes untuk memenuhi kebutuhan masyarakat, perspektif bahwa CSR merupakan dasar bagi perusahaan modern telah berkembang selama beberapa dekade terakhir dari Friedman (1970), pandangan minimalis tentang peran bisnis dalam masyarakat.

Tekanan publik terhadap BUMDes untuk melakukan kegiatan yang bernuansa tanggung jawab sosial diprediksi akan terus meningkat seiring berjalannya waktu karena berbagai alasan termasuk: 1) BUMDes mempunyai akses langsung ke sumber daya (misalnya modal, tenaga kerja, jaringan) yang tidak dimiliki oleh struktur usaha lain di sekitar desa; 2) Rasa "frustrasi" publik dengan organisasi lain (misal organisasi nirlaba dan organisasi non-pemerintah seperti LSM yang gagal mengatasi masalah sosial; dan 3) Kegagalan perusahaan atau bisnis yang ada di sekitar wilayah desa untuk memikul tanggung jawab atas masalah yang mereka ciptakan.
Menurut Carroll, keempat kategori tanggung jawab sosial yang dilakukan perusahaan selalu ada sampai batas tertentu. Argumen pentingnya adalah bahwa perusahaan perlu memenuhi keempat aspek tanggung jawab sosial secara bersamaan. Carroll menyatakan bahwa tanggung jawab ekonomi dan hukum dianggap "diperlukan atau dibutuhkan" secara sosial, tanggung jawab etis dipandang sebagai hal yang "diinginkan" secara sosial, dan filantropi dianggap sebagai yang "diharapkan" secara sosial. Sebagai hasilnya, Carroll (1991) mengusulkan bahwa sebuah perusahaan harus berusaha untuk mendapatkan untung, mematuhi hukum, menjadi etis, dan menjadi bagian dari masyarakat yang baik untuk menerapkan tanggung jawab sosialnya. Model asli Carroll pada tahun 1979 tersebut dianggap sebagai tonggak sejarah untuk studi kinerja sosial perusahaan untuk periode selanjutnya.

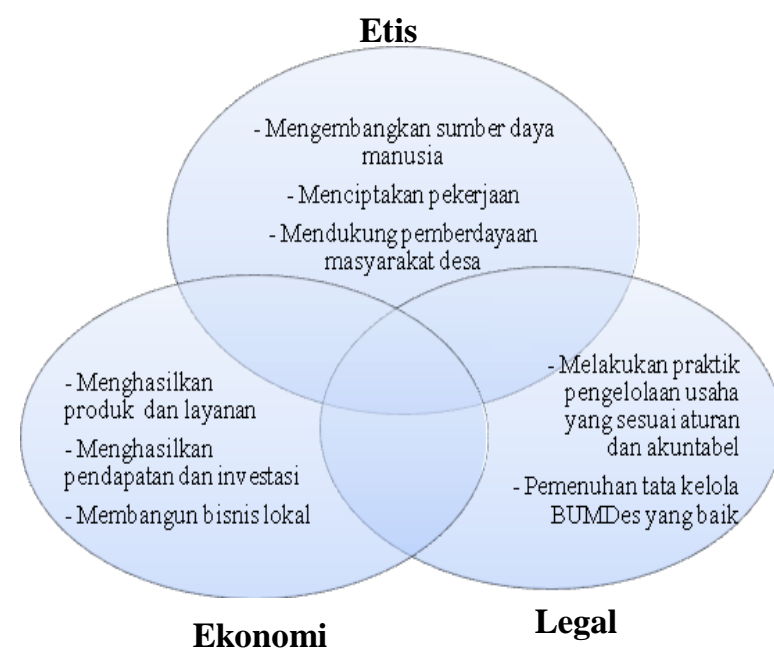

Gambar 3. Domain Tanggung Jawab Sosial Pada BUMDes

Kerangka model Carroll dalam kategori tanggung jawab sosial tersebut menyiratkan bahwa sebuah usaha dalam hal ini harus bertanggung jawab untuk menjadi profitabel dan mematuhi aturan, keduanya adalah nilai mendasar yang "diperlukan" dalam legitimasi sebuah usaha ketika menjalankan praktik tanggung jawab sosialnya. Sehingga tanggung jawab sosial dari Bumdes paling awal dan minimal adalah bagaimana menjadi profitabel dan mematuhi aturan yang berlaku. Aspek 
bisnis atau pengelolaan potensi ekonomi pada suatu wilayah desa yang dikelola bumdes seharusnya dapat berorientasi profit terlebih dahulu sebelum memposisikan diri sebagai kegiatan berbasis sosial yang cenderung philantropi.

Gambar 3 menunjukkan kerangka tanggung jawab sosial BUMDes dengan tiga domain utamanya, dapat dijelaskan bahwa secara aspek ekonomi BUMDes dapat bertindak menunjukkan tanggung jawab sosialnya antara lain dengan: 1) Menghasilkan produk dan layanan. Penciptaan produk barang atau layanan ini merupakan akar utama dari tanggung jawab sosial BUMDes, untuk meningkatkan skala kapasitas ekonomi yang dimilikinya, 2) Menghasilkan pendapatan dan investasi. Produk dan atau layanan yang dihasilkan menjadi media BUMDes dalam mendapatkan penghasilan maupun mendorong investasi dari pemilik modal (misal pemilik modal dari desa setempat atau yang menjadi perantau sukses di tempat lain), 3) Membangun bisnis lokal. Tujuan dari bisnis adalah untuk menciptakan profit, BUMDes harus mempertimbangkan hal ini dengan seksama agar keberlanjutan badan usaha tersebut dapat berjalan lama bukan hanya gegap gempita sesaat dari kebijakan pemerintah. Dengan membangun bisnis lokal maka hal ini akan mendukung kapabilitas ekonomi desa, dan BUMDes dapat berperan lebih dalam hal ini.

Selanjutnya aspek legal dari BUMDes menunjukkan tanggung jawab sosialnya dalm bentuk tindakan antara lain: 1) Melakukan praktik pengelolaan usaha yang sesuai aturan dan akuntabel. Pratik pengelolaan usaha sesuai aturan ini sangat penting agar tidak terjadi kesalahan administratif yang berdampak pada penurunan kinerja dari BUMDes; 2) Pemenuhan tata kelola BUMDes yang baik. BUMDes merupakan entitas bisnis (meskipun mempunyai misi sosial) yang harus memenuhi kaidah tata kelola yang baik. Hal ini penting untuk menghindari konflik kepentingan yang mungkin terjadi pada organisasi BUMDes sehingga tujuan BUMDes dapat tercapai secara efisien dan efektif.
Sementara aspek etis dari tanggung jawab sosial BUMDes dapat ditunjukkan antara lain dengan : 1) Mengembangkan sumber daya manusia. Pengembangan SDM dalam masyarakat desa menjadi perwujudan riil dari misi sosial BUMDes. Hal ini sangat erat terkait dengan kegiatan pemberdayaan masyarakat desa; 2) Menciptakan pekerjaan. BUMDes tidak sebagai lembaga atau institusi pemberi kerja, tetapi yang mendorong terciptanya pekerjaan baru di sekitar masyarakat. Hal ini terkait dengan pengembangan SDM dalam konteks pemberdayaan masyarakat. Sebagai contoh bentuk adalah memberikan pelatihan pengembangan usaha untuk perempuan di masyarakat sekitar untuk meningkatkan kapasitas ekonomi dari usaha kecil dan menengah; dan 3) Mendukung praktek pemberdayaan masyarakat desa. BUMDes menjadi entitas yang dapat berperan strategis dalam pemberdayaan masyarakat desa melalui konektivitasnya dengan unsur masyarakat tetapi bukan sebagai bagian dari pelaksana pemerintahan.

\section{Kesimpulan}

Praktek tanggung jawab sosial (social responsibility) pada BUMDes belum atau tidak menjadi ranah yang menarik atau bahkan mempunyai urgensi untuk dikaji. Tetapi dengan praktek tanggung jawab sosial yang baik dan efektif, maka dapat diasumsikan untuk selanjutnya bahwa dengan menyeimbangkan kepentingan berbagai pemangku kepentingan maka hal ini akan memastikan tercapainya pertumbuhan dan pembangunan berkelanjutan dalam jangka panjang bagi BUMDes. Namun, asumsi tanggung jawab sosial yang membutuhkan aktivitas sukarela sangat mungkin untuk diperdebatkan lebih lanjut. Berbagai pendapat dapat muncul ketika membahas kemampuan BUMDes untuk terlibat dalam program sosial dan nilai potensi dari praktek tanggung jawab sosialnya. Di satu sisi, BUMDes tidak diragukan lagi adalah bagian dari masyarakat desa dan sebagian besar bertanggung jawab atas pembangunan sosial dan ekonomi di desa. Oleh karena itu, BUMDes harus 
memikul tanggung jawab atas tantangan dan masalah saat ini sebagai hasil dari kegiatannya. Di sisi lain BUMDes mempunyai posisi strategis dan dengan keterlibatan dalam program sosial dapat meningkatkan dampaknya terhadap masyarakat dan meningkatkan risiko penyalahgunaan kekuasaan.

Inti dari debat tentang tanggungjawab sosial pada BUMDes adalah gagasan bahwa BUMDes harus bertransisi dari kondisi kepatuhan atau kebutuhan semata (profit dan kesesuaian terhadap aturan) ke dalam bentuk keterlibatan, dari minimalisir bahaya atau konsekuensi negatif (dampak sosial dan lingkungan) ke penciptaan nilai. BUMDes adalah mesin pertumbuhan ekonomi yang dominan sebagai pencipta prinsip nilai dan sumber daya manajerial, dan bahwa BUMDes memiliki kewajiban untuk berkontribusi pada pertumbuhan ekonomi masyarakat desa dengan adil dan berkelanjutan.

Dalam pengembangan BUMDes disarankan memasukkan harapan pemangku kepentingan (stakeholders) ke dalam strategi pengembangan BUMDes dan melibatkannya dalam kegiatan tanggung jawab sosial BUMDes. Idealnya adalah praktek tanggung jawab sosial yang dapat dilakukan oleh BUMDes sebagai upaya memenuhi ketiga aspek (ekonomi, legal, dan etis). Tetapi, pemenuhan tanggung jawab dari kedua fokus di sini adalah tanggung jawab ekonomi dan legal atau hukum dalam BUMDes. Dari perspektif keduanya, BUMDes diharapkan dapat memikul tanggung jawab dan kepatuhan terhadap prinsip-prinsip moralitas, akuntabilitas, dan integritas dengan cakupan potensi kontribusi dan intervensi yang jauh lebih luas lagi untuk mendorong kesinambungan diantara stakeholder serta meningkatkan keberlanjutan dari bisnis yang dijalankan BUMDes.

Keberadaan BUMDes diyakini sarat mengandung aspek sosial (pemberdayaan masyarakat desa) selain aspek ekonomi (peningkatan ekonomi masyarakat desa). Dalam prakteknya di masa depan, pengelolaan BUMDes disarankan dapat memperhatikan ketiga aspek penting yakni aspek etis, ekonomi, dan legal. Peningkatan kualitas kelembagaan BUMDes hendaknya dapat dimulai dengan memberikan legalitas yang tepat sehingga BUMDes dapat memaksimalkan peningkatan potensi desa.

\section{DAFTAR PUSTAKA}

Azwardi, A., \& Sukanto, S. (2014). Efektivitas Alokasi Dana Desa (ADD) dan Kemiskinan di Provinsi Sumatera Selatan. Jurnal Ekonomi Pembangunan, 12(1), 29-41.

Bhattacharya, S. S., Sahay, A., Arora, A. P., \& Chaturvedi, A. (2004). A toolkit for designing firm level strategic corporate social responsibility (CSR) initiatives. Social Responsibility Journal, 4(3), 265-282.

Carroll, A. B. (1991). The Pyramid of Corporate Social Responsibility: Toward the Moral Management of Organizational Stakeholders. Business Horizons, (July-Agustus), 39-48.

Clarkson, M. B. E. (1995). A Stakeholder Framework for Analyzing and Evaluating Corporate Social Performance. The Academy of Management Review, 20(1), 92-117.

Dahlsrud, A. (2008). How Corporate Social Responsibility is Defined: an Analysis of 37 Definitions. Corporate Social Responsibility and Environmental Management, 15(1), 1-13.

Eberle, D., G.Berens, \& Li, T. (2013). The Impact of Interactive Corporate Social Responsibility Communication on Corporate Reputation. Journal of Business Ethics, 118, 731-746.

Frederick, W. C. (1998). Creatures, corporations, communities, chaos, complexity: a naturological view of the corporate social role. Business \& Society, 37(4), 358-389.

Freeman, R. E. (1994). The politics of stakeholder theory. Business Ethics Quarterly, 4(4), 409-421.

Freeman, R. E., Wicks, A. C., \& Parmar, B. (2004). Stakeholder Theory and "The Corporate Objective Revisited." Organization Science, 15(3), 364-369. 
Friedman, M. (1970, September 13). The social responsibility of business is to increase its profits. New York Times Magazine.

Harrison, J. S., \& Freeman, R. E. (1999). Stakeholders, social responsibility, and performance: Empirical evidence and theoretical perspective. Academy of Management Journal, 42(5), 479-485.

Hou, J., \& Reber, B. H. (2011). Dimensions of disclosures: Corporate social responsibility (CSR) reporting by media companies. Public Relations Review, (37), 166-168.

Husted, W. B., \& Allen, D. B. (2007). Strategic Social Responsibility and value Creation among large Firms Lessons from the Spanish Experience. Long Range Planning, 40(6), 594-610.

Jamali, D., \& Mirshak, R. (2007). Corporate Social Responsibility (CSR): Theory and Practice in a Developing Country Context. Journal of Business Ethics, 72, 243-262.

Kolopaking, L. M., Septianto, M., \& Ambarita, E. (2019). Sinergi Pengelolaan Desa Membangun Dengan Kegiatan Corporate Social Responsibility (Studi Kasus PT. Indonesia Power, Gunung Salak). Sodality: Jurnal Sosiologi Pedesaan, (Agustus 2019), 102-109.

Kristia. (2019). Model Bisnis Triple Bottom Line Pasar Komunitas Makanan Sehat dan Pengembangannya dalam Mewujudkan Rantai Pasok Pangan Berkelanjutan. Jurnal Manajemen \& Kewirausahaan, 7(2), 139 - 153.

Luo, X., \& Bhattacharya, C. B. (2006). Corporate social responsibility, customer satisfaction, and market value. Journal of Marketing, 70(4), 118.

Nurbaiti, S. R., \& Bambang, A. N. (2017). Faktor - Faktor yang Mempengaruhi Partisipasi Masyarakat dalam Pelaksanaan Program Corporate Social Responsibility (CSR). In Proceeding Biology Education Conference (pp. 224-228).
Phillips, R., Freeman, R. E., \& Wicks, A. C. (2003). What Stakeholder Theory is Not. Business Ethic Quarterly, 13(4), $479-502$.

Sen, S., \& Bhattacharya, C. B. (2001). Does Doing Good Always Lead to Doing Better? Consumer Reactions to Corporate Social Responsibility. Journal of Marketing Research, 38(2), 225-243.

Sen, S., Bhattacharya, C. B., \& Korschun, D. (2006). The Role of Corporate Social Responsibility in Strengthening Multiple Stakeholder Relationships: A Field Experiment. Journal of the Academy of Marketing Science, 34(2), 158-166. 